\title{
An Analysis of Coherence of Chinese Courtroom Discourse
}

\author{
Guang Shi
}

\author{
Department of English, School of Foreign Languages and Cultures, Nanjing Normal University, China
}

\begin{abstract}
Coherence, the relationships which link the meanings of utterances in a discourse or of the sentences in a text, is realized on two levels: linear or sequential coherence and global semantic structure. Taking the audio recording transcripts of two trials (one criminal and one civil) as data, this paper analyzes coherence of Chinese courtroom discourse. The findings indicate that courtroom discourse is coherent semantically (there are meaning relations between different parts of the discourse), topically (different parts of the discourse accord with its general topic), contextually (different parts of the discourse mix with the context and accomplish the communication together), and historically (the discourse refers back to its history, i.e. preceding trials, etc).
\end{abstract}

Keywords: Coherence, Chinese courtroom discourse, Meaning, Civil trial, Criminal trial.

\section{INTRODUCTION}

As a typical institutional discourse, courtroom discourse is strongly purpose-driven, because it involves important rights, interests and concerns, e.g., life, property, reputation, etc. "The purpose of the courtroom discourse is very clear and definite" (Liao 2012: 86). In order to realize the purpose, courtroom discourse should be understood clearly, which requires it to be coherent. Without coherence, courtroom discourse would be just accumulation of words and expressions and thus would be confusing. How can confusing discourse convince others and realize its purpose? So it is essential for courtroom participants to produce coherent discourse. This paper analyzes the linguistic mechanisms for the coherence of courtroom discourse.

The study of coherence in discourse analysis dates back to the early 1960s. However it is the book Cohesion in English published by Halliday and Hasan in 1976 that really attracted researchers' attention. With the development of the research, several theories have been put forward, i.e., Halliday and Hasan's cohesion theory (1976), van Dijk's macrostructure theory (1977, 1980), Widdowson's illocutionary act theory (1978), Mann and Thompson's rhetorical structure theory (1988), Brown and Yule's cognitive frame theory (1983), Danes and Fries' thematic progression theory (1974), Sanders, Spooren and Noordman's cognitive parameterization theory $(1992,1993)$. Of the above, van Dijk's $(1977,1980)$ macrostructure theory is most suitable for the analysis of such institutional discourse as courtroom discourse (Tao 2009: 102, Wang 2009: 125).

*Address correspondence to this author at the Department of English, School of Foreign Languages and Cultures, Nanjing Normal University, China; Tel/Fax: +86 25 83598181; E-mail: sgbright@163.com
Coherence of legal language has attracted scholars' attention and some research has been conducted. However, previous studies mainly focus on legislative text. For example, Xiong (2002), Huang (2008), Hu (2010) and Yang and Jiang (2014) all examined coherence of Chinese legislative text, taking Constitution of China and various laws as data. Liao $(2003,2012)$ touched upon coherence of Chinese courtroom discourse from the perspectives of questionanswer interaction and frame analysis. Lv (2011) explored coherence in her discussion of power relations in Chinese courtroom discourse. Up to now, no scholars have employed van Dijk's macrostructure theory to analyze coherence of Chinese courtroom. This paper is a preliminary attempt in this regard.

\section{COHERENCE}

Coherence refers to the relationships which link the meanings of utterances in a discourse or of the sentences in a text. Van Dijk (1977 : 95) points out that coherence of text is realized on two levels: 'linear or sequential coherence' and 'global overall coherence', i.e. coherence of the 'macrostructure'. The former refers to 'the coherence relations holding between propositions expressed by composite sentences and sequences of sentences', which has three aspects: 1) the sequence of the narration of facts or content, including the sequence of knowing things according to conventions; 2) the preciseness and explicitness of the narration of facts and content; and 3) the organization and development of the information in the text, the interaction of given and new information, etc. The macrostructure of the text refers to the semantic structure represented by the general topic that governs the whole text. So a coherent text is a text whose constituent parts (episodes, sentences) are meaningfully related so that the text as a whole makes sense, even though there may be relatively few formal 
markers of those meaningful relationships-that is, relatively little explicit cohesion. So coherence has to do with the global meaning involved in what we want to express through our speech activity (Mey 2001: 154).

Zhang and Liu (2003:10) argue that the three requirements for a text to be coherent are: 1) semantic coherence, which means that there should be meaning relations between the parts of a text; 2) topical coherence, requiring that the parts of a text should accord with its general topic; and 3) contextual coherence, meaning that the parts of a text mix with the context and accomplish the communication together.

In the analysis of data, I find that courtroom participants refer back to the discourse of preceding trials frequently. For example:

Extract 1

Appellant: Yuánshěn pànjué chá míng, "Kāifā gōngsī xiàng nánjīng shì jiànwěi shēnqǐng quèrèn hàn fŭ yă yuàn wèi gāodàng zhùzhái xiăoqū.2000 Nián 10 yuè 24 rì, nánjīng shì jiànwěi zài bèigào nánjīng zhăng fā wùyè guănlĭ yǒuxiàn gōngsĩ de bàogào zhōng xiěle "qíngkuàng shǔshi" de ziyàng". Shàngsù rén rènwéi zhè shì yīgè rènding de cuòwù.

The judgment of the original trial says, "The property development company applied to Nanjing Municipal

Commission of Housing and Urban-Rural Development to confirm Hanfu Yayuan to be a high-grade residential village. On Oct. 24, 2000, Nanjing Municipal Commission of Housing and

Urban-Rural Development verified the report submitted by the defendant". The appellant thinks that this is a wrong verification.

In Extract 1, the appellant quotes what is said in the judgment of the original trial and comments on it. This builds the link between the current trial and its history, i.e. the original trial (first instance).

Extract 2 Prosecutor: Is your previous confession true?

Defendant: Yes.

In Extract 2, the prosecutor asks the defendant to comment on his previous confession. The defendant responds accordingly. This question-answer interaction (see Liao 2003 for a detailed analysis of questionanswer interactions in Chinese courtroom discourse) performs the same function as the appellant's statement in Extract 1, i.e. builds the link between the current trial with its history (the defendant's confession in the preceding police interrogation).

The discourse strategy in the above two extracts figures prominently in the trials. Actually, it is used frequently by almost all the trial participants. Its function is to link the current trial with its history (i.e. what happened or was said before). It plays an important role in achieving the coherence of courtroom discourse, because it provides the 'context of situation' (Malinowski 1923) of the trial. It is termed 'historical coherence'.

The above discourse strategy, i.e. historical coherence, can also be analyzed from the perspective of intertextuality ${ }^{1}$, which is the topic addressed in another paper of mine (Shi 2014).

\section{COHERENCE OF CHINESE COURTROOM DISCOURSE}

In this section, two trials (one civil and one criminal) will be analyzed to demonstrate the coherence of Chinese courtroom discourse. Let's first look at a civil trial.

\section{Coherence of a Civil Trial}

This is a civil trial involving property management fee dispute. The fact of this case is as follows: $\mathrm{Xu}$ (male) and $\mathrm{Li}$ (male), two property owners at Hanfu Garden (the name of a housing estate), refused to pay the property management fee from March 1, 2002 because they thought that the property management company at Hanfu Garden (Nanjing Changfa Property Management Co., Ltd, henceforth NCPM) was not qualified to charge the fee and its basis and standard for fee-charging was illegal. NCPM sued $X u$ and Li to Xuanwu District People's Court of Nanjing (henceforth XDPC). XDPC ruled that $\mathrm{Xu}$ and $\mathrm{Li}$ should pay the property management fee. $\mathrm{Xu}$ and $\mathrm{Li}$ refused to accept the verdict and appealed to Nanjing Intermediate People's Court (henceforth NIPC). The following extract is taken from the stage of court investigation, in which the presiding judge is inquiring the appellee agent on the standard for charging the property management fee at a certain period of time:

\section{Extract 3}

\begin{tabular}{|c|c|c|}
\hline T1 & Judge: & $\begin{array}{l}\text { Nǐwèishéme yào àn zhège biāozhǔn } \\
\text { shōufèi? }\end{array}$ \\
\hline [2 & Appellee agent: & $\begin{array}{l}\text { Yīnwèi wǒmen shì qìngshì le wùjià jú } \\
\text { de. }\end{array}$ \\
\hline & Judge: & Qǐngshì le wùjià jú? \\
\hline & Appellee agent: & Duì \\
\hline
\end{tabular}

${ }^{1}$ Intertextuality is basically the property texts have of being full of snatches of other texts, which may be explicitly demarcated or merged in, and which text may assimilate, contradict, ironically echo, and so forth (Fairclough 1992: 84). 


\begin{tabular}{|c|c|c|}
\hline T5 & Judge: & $\begin{array}{l}\text { Qǐngshì le nánjīng shì wùjià jú? Wùjià } \\
\text { jú tóngyì le? Jìxù tóngyì nì àn zhège } \\
\text { biāozhǔn shōufèi? Shì bùshì? }\end{array}$ \\
\hline T6 & Appellee agent: & $\begin{array}{l}\text { Wùjià jú ràng wǒmen jǐnkuài chénglì } \\
\text { yèzhǔ wěiyuánhuì. }\end{array}$ \\
\hline T7 & Judge: & $\begin{array}{l}\text { Duì a, nǐmen yèzhǔ wěiyuánhuì bùshì } \\
\text { méiyǒu chénglì ma? Nǐ zhè duàn } \\
\text { shíjiān zhège kòngquē shì zěnme shōu } \\
\text { de ne? }\end{array}$ \\
\hline T8 & Appellee agent: & Wǒ zhège shōufèi shì yèzhǔ tóngyì de. \\
\hline T9 & Judge: & Năge yèzhǔ? \\
\hline T10 & Appellee agent: & Suǒyǒu yèzhǔ. \\
\hline $\mathrm{T} 11$ & Judge: & $\begin{array}{l}\text { Suǒyǒu yèzhǔ. Zhè shì zěnme kàn } \\
\text { chūlái de ne? }\end{array}$ \\
\hline T12 & Appellee agent: & $\begin{array}{l}\text { Cóng shōufèi de qíngkuàng kěyǐ kàn } \\
\text { chū. Shōufèi de shōujù. }\end{array}$ \\
\hline T13 & Judge: & $\begin{array}{l}\text { Nǐmen xiàng suǒyǒu de yèzhǔ dōu } \\
\text { zhēngqiú yìjiàn le ma? }\end{array}$ \\
\hline $\mathrm{T} 14$ & Appellee agent: & Suǒyǒu de dōu shì zhèyàng shōu de. \\
\hline T15 & Judge: & $\begin{array}{l}\text { Jiùshì shuō nǐ bùguăn yuànyì bù yuànyì } \\
\text { de nǐ jiù zhèyàng shōu le? }\end{array}$ \\
\hline T16 & Appellee agent: & $\begin{array}{l}\text { Suǒyǒu de dōu shì zhèyàng shōu de. } \\
\text { Děng dìng le xīn de jiàgé duō shōu de } \\
\text { zài tuì. }\end{array}$ \\
\hline T17 & Judge: & $\begin{array}{l}\text { Jiùshì shuō nì gěi dàjiā jiăng: Pīwén } \\
\text { xiànzài yịjīng guòqí le, yèzhǔ } \\
\text { wěiyuánhuì hái méiyǒu chénglì, xiànzài } \\
\text { zhège kòngquē, réngrán àn liăng kuài } \\
\text { liù shōu. Shì zhège yìsi ba? }\end{array}$ \\
\hline T18 & Appellee agent: & Shì. \\
\hline T19 & Judge: & $\begin{array}{l}\text { Zhè duàn shíjiān shōufèi biāozhǔn shì } \\
\text { àn shénme kào de? Jiùshì liăng kuài } \\
\text { liù? Hái tuì bù tuì le? }\end{array}$ \\
\hline T20 & Appellee agent: & Bù tuì. \\
\hline T21 & Judge: & Nà zhè shì shénme yìsi ne? \\
\hline T22 & Appellee agent: & Méishénme yìsi \\
\hline T23 & Judge: & $\boldsymbol{\nabla}$ Wǒ jiù dìng le, jiù àn zhège shōu. \\
\hline 'T1 & Judge: & $\begin{array}{l}\text { Why did you charge according to this } \\
\text { standard? }\end{array}$ \\
\hline $\mathrm{T} 2$ & Appellee agent: & $\begin{array}{l}\text { Because we had consulted the Bureau } \\
\text { of Commodity Prices. }\end{array}$ \\
\hline T3 & Judge: & $\begin{array}{l}\text { You had consulted the Bureau of } \\
\text { Commodity Prices? }\end{array}$ \\
\hline $\mathrm{T} 4$ & Appellee agent: & Yes. \\
\hline T5 & Judge: & $\begin{array}{l}\text { You had consulted the Bureau of } \\
\text { Commodity Prices of Nanjing? Did the } \\
\text { Bureau approve? It allowed you to go } \\
\text { on with the charge according to the } \\
\text { standard, right? }\end{array}$ \\
\hline T6 & Appellee agent: & $\begin{array}{l}\text { The Bureau asked us to set up the } \\
\text { Property Owners Committee as soon } \\
\text { as possible. }\end{array}$ \\
\hline T7 & Judge: & $\begin{array}{l}\text { Right, you had not set up the } \\
\text { Committee, had you? During this } \\
\text { period, how did you charge the fee? }\end{array}$ \\
\hline T8 & Appellee agent: & $\begin{array}{l}\text { The property owners agreed to our } \\
\text { charge. }\end{array}$ \\
\hline
\end{tabular}

\begin{tabular}{|c|c|c|}
\hline T9 & Judge: & Which property owners? \\
\hline $\mathrm{T} 10$ & Appellee agent: & All of them. \\
\hline $\mathrm{T} 11$ & Judge: & All of them. How can you tell? \\
\hline $\mathrm{T} 12$ & Appellee agent: & $\begin{array}{l}\text { It can be seen from the charges, the } \\
\text { receipts. }\end{array}$ \\
\hline T13 & Judge: & $\begin{array}{l}\text { Did you consult all the property } \\
\text { owners? }\end{array}$ \\
\hline $\mathrm{T} 14$ & Appellee agent: & We charged them all like this. \\
\hline T15 & Judge: & $\begin{array}{l}\text { Do you mean, you charged them like } \\
\text { this, no matter whether they agreed or } \\
\text { not? }\end{array}$ \\
\hline T16 & Appellee agent: & $\begin{array}{l}\text { All were charged like this. We planned } \\
\text { to refund the overcharged property } \\
\text { owners when the new price was set. }\end{array}$ \\
\hline $\mathrm{T} 17$ & Judge: & $\begin{array}{l}\text { Do you mean you told them: "the } \\
\text { original approval now expires, but the } \\
\text { Property Owners' Committee has not } \\
\text { been set up, so during this period, the } \\
\text { charge is still } ¥ 2.6 / \mathrm{m}^{2} " \text {, is that right? }\end{array}$ \\
\hline T18 & Appellee agent: & Yes. \\
\hline T19 & Judge: & $\begin{array}{l}\text { What was the standard for charge in } \\
\text { this period? Just } ¥ 2.6 / \mathrm{m}^{2} \text { ? Would it be } \\
\text { refunded? }\end{array}$ \\
\hline T20 & Appellee agent: & No. \\
\hline $\mathrm{T} 21$ & Judge: & What do you mean? \\
\hline T22 & Appellee agent: & No meaning \\
\hline T23 & Judge: & $\begin{array}{l}\nabla \text { l just set the price, and charge } \\
\text { accordingly?' }\end{array}$ \\
\hline
\end{tabular}

Extract 3 meets all the three requirements for coherence. First, let's analyze semantic coherence. Some key words or phrases, which are closely related to the topic of this stage, appear recurrently. For example, shōufèi 'charge' is used 14 times, biāozhǔn 'standard' 4 times, wùjià jú 'Bureau of Commodity Prices' 4 times, and yèzhǔ wěiyuánhuì 'Property Owners' Committee' 4 times. The most important word 'shōufèi 'charge' is scattered in the extract and is almost equally used by both speakers: 8 times by the judge and 6 times by the appellee agent, which shows that the whole extract is semantically linked up by this key term. Furthermore, the recurrent appearance of such key words as shōufèi 'charge', biāozhǔn 'standard', wùjià jú 'Bureau of Commodity Prices', and yèzhǔ wèiyuánhuì 'Property Owners' Committee' shows that the interaction of given and new information is systematic. In a word, the whole extract is semantically coherent.

Another feature is topical coherence. This extract can be roughly divided into three parts: $T 1$ to $T 7, T 8$ to T16 and T17 to T23. In the first seven turns, the judge inquires on the standard for charging the property management fee at a certain period of time, but the 
appellee agent doesn't give a definite answer. In T8, the appellee agent attempts to distract the judge's attention by introducing a new topic: i.e., the charge was approved by the property owners. His strategy is successful and the judge is led to this "new" topic, which is the focus of attention in the next nine turns. However, in T17, the judge realizes the trick played by the appellee agent and tactfully leads the conversation back to the original topic, i.e. the standard for the charge (pay attention to réngrán àn liăng kuài liù shōu

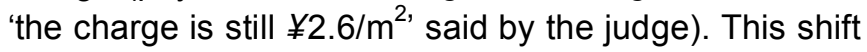
of topic throws the appellee agent into an unfavorable situation, and he has to acknowledge that the standard for the charge at that period was $¥ 2.6 / \mathrm{m}^{2}$. In this way, the judge accomplishes her objective, i.e. to find out the standard for charging the property management fee at the period of time in question. In a word, although the extract can be divided into three parts, it is coherent as a whole because of its topical coherence.

The extract is also contextually coherent. It is a part of a civil trial, which is a social activity conducted at a court. So it belongs to institutional discourse. Specifically, it is a part of court investigation, in which the judge inquires the appellee agent on some facts. Both speakers have their own purposes: the judge wants to find out the truth of the fact while the appellee agent tries to say something in favour of his client. Their purposes make them cooperate and also "struggle" with each other, which renders the extract integrated and coherent.

T17 deserves our special attention because it demonstrates historical coherence. The judge says, "Do you mean you told them: "the original approval now expires, but the Property Owners' Committee has not been set up, so during this period, the charge is still $¥ 2.6 / \mathrm{m}^{2}$ ", is that right?". The judge's discourse refers back to what the appellee said in the past, which links the utterance here with its history, i.e. relevant discourse before this trial.

\section{Coherence of a Criminal Trial}

This section analyzes a criminal trial involving theft, the fact of which is as follows: Li (male, 16 years old) and $\mathrm{Wu}$ (male, 16 years old) dropped school and went to Jiangning District of Nanjing in August 2006. Lured by Zhao (who is at large), they began to participate in thefts with some other youngsters. Altogether $\mathrm{Li}$ participated in 11 thefts and $\mathrm{Wu} 8$. Wu was caught on the spot in his last theft but $\mathrm{Li}$, Zhao and another youngster fled the scene. After he was caught, Wu led

the policemen to the place where he and other youngsters stayed. Li was caught there but Zhao and other youngsters fled again. They were still at large when the case was tried on Jan. 15, 2007.

In a criminal trial, usually it's the prosecutor who interrogates the defendant. In this case, the interrogation of the prosecutor on the defendants takes up the major part of the trial and thus figures prominently. See the following extract in which the prosecutor interrogates $\mathrm{Wu}$ on the 8 thefts he participated in (The following extract is a modified version of the original transcript to save space):

Extract 4

T1 Prosecutor: Nǐshì zěnme hé zhào mǒu mǒu, li mǒu

T2

Defendant: mǒu tāmen rènshi de?

T3

Prosecutor:

Wǒ 1 yuèfèn rènshi zhào mǒu mǒu de, dāngshí yě bù zhīdào tā gàn shénme de.

T4 Defendant:

Nì shì shénme shíhou lái nánjīng de?

Qùnián bā yuèfèn. Nèitiān shì zhào mǒu mǒu jiào wǒ guòlái shuō péi tā wán jĩ tiān, yě méiyǒu shuō guòlái gànshénme.

T5

Prosecutor:

Bă nì jiē guòlái zhīhòu, nǐ dì yīcì dàoqiè zhào mǒu mǒu yǒu méiyǒu gēn nǐ jiăng qù gànshénme?

T6 Defendant:

Méiyǒu. Dàole nà biān yǐhòu tā cái gēn wǒ jiăng qù tōu dōngxi, dāngshí wǒ jiù zài wàimiàn wàngfēng.

T7 Prosecutor

Chú liǎo wàngfēng y̌̌wài nǐ hái yǒu shé me xíngwéi?

T8 Defendant:

Dì yīcì méiyǒu.

T9 Prosecutor:

Dì yīcì dì dìdiăn nǐ zhīdào ma?

T10

Defendant:

Zhīdào, hòulái biànrèn le.

T11 Prosecutor:

Tāmen tōu le shénme dōngxi nì zhīdào ma?

T12 Defendant:

MP3, xiǎo língtōng, diànnǎo nèicún tiáo, dōngxi tōu lái zhīhòu fàng zài zhào mǒu mǒu nà.

Prosecutor:

Dì èr cì ne?

T14 Defendant:

Tóngyī tiān xiàwǔ, háishì wǒmen sì gèrén, wǒ yě jìnqù le, zhào mǒu mǒu bāi chuānghù, ránhòu li mǒu mǒu jìnqù bămén dăkāi, wǒmen jiù dōu jìnqù le, zhè yīcì tōu le xiàngliàn yītiáo, jīn jièzhì èr gè, yínyuán sān gè, Xiànjīn bù qīngchu. Zhèxiē dōngxi dū shì wǒmen zijīi zhăo, ránhòu fàng dào yīqĭ de.

T15

$\mathrm{T} 16$

T17

T18
Prosecutor:

Defendant:

Prosecutor:

Defendant:
Shǒushì hòulái zěnme chǔlĭ le?

Wǒmen yīqŭ qù mài diào le. Mài le 1350 yuán. Zhèxiē qián zhíjiē jiù gěi zhào mǒu mǒu le. Hòulái dàjiā yì qĭ chīfàn yòng diào le.

Dì sāncì ne?

Háishì wǒmen sì gèrén, zài yīgè xiăoqū de yī lóu, yóu zhào mǒu mǒu bāi chuānghù, li mǒu mǒu zuān jìnqù, dăkāi 
mén fàng wǒmen jìnqù, zhè cì tōu le yìng zhōnghuá 6 bāo, wǔ liáng chūn 2 píng, jiư mài le 90 Kuài qián, yān rénjiā bù shōu, yīnwèi zhè shì chūkǒu xiāngyān, hòulái wǒmen jiù zijīi chōu diào le. Zhège qián yěshì fàng zài zhào mǒu mǒu nà, wǒmen dàjiā yì qĭ huā diào le.

\section{T19 \\ Prosecutor:}

Dì sìcì ne?

Defendant:

Wǒmen sì gèrén zài yīgè diàn lǐmiàn, tōu le 500 kuài qián, fàng zài zhào mǒu mǒu nà, dàjiā yì qĭ huā le.

Prosecutor:

Dì wŭ cì ne?

Defendant:

Prosecutor:
Prosecutor:

Defendant:

Prosecutor:

Defendant:

Prosecutor:

Defendant:

Prosecutor:

Defendant:

Prosecutor:

Defendant:

Prosecutor:

Defendant

Prosecutor:

Defendant:

Prosecutor:

Defendant:

Prosecutor:

Defendant:
Sān gèrén, méiyǒu zhào mǒu mǒu, zhè ci shì li mǒu mǒu bāi chuānghù de, ránhòu wǒmen dàjiā yì qǐ jìnqù tōu le xiànjīn rénmínbì 100 duō yīdiăn, dàgài yǒu 120 kuài qián. Zhège qián wǒmen ná huíqù zhīhòu gěi le zhào mǒu mǒu.

Dì liù cì ne?

Háishì wǒmen sān gèrén, méiyǒu zhào mǒu mǒu, zhè cì shì li mǒu mǒu bāi chuānghù de, wǒmen sān gèrén yīqù jìnqù, zhè cì tōu le huángjīn xiàngliàn yītiáo, èr méi jièzhì, yùpèi yīgè, xiànjīn děng.

\section{Shǒushì dào nă qù le?}

Mài le 2/40 yuán. Shì li mǒu mǒu qù mài de.

\section{Nà nǐ zěnme zhīdào de?}

Li mǒu mǒu mài liăo zhīhòu gěi le zhào mǒu mǒu de, suǒyĭ wǒ jiù zhīdào le.

Dì Qīcì ne?

Wǒmen sì gèrén yīqǐ jìnqù de, tōu le shǒujī, zhōng héng pái MP4, xiànjīn.

Zhèxiē dōngxi hòulái zěnme chǔlǐ le?

Shǒujī,MP4 bèi zhuā de shíhou gěi kòu le, xiànjīn fàng zài zhào mǒu mǒu nà le.

\section{Zuihòu yīcì ne?}

Wǒmen sì gèrén yīqĭ qù de. Zhào mǒu mǒu bāi kāi chuāng hù, ránhòu wǒ zuān jìnqù, tōu le 200 duō kuài qián xiànjīn, èrtiáo xiàngliàn, èr zhǐ jièzhì zhèxiē dōngxi bèi zhuā de shíhou dōu gěi kòu le.

Nĩ shì rúhé pī fà xiàn de?

Wǒ tōu le dōngxi zhǔnbèi dăkāi mén ràng rén fà xiàn de, nàrén zài wūzi wàimiàn de.

Nĩ dăkāi mén de shíhou sān gèrén zài bùzài?

Bùzài?

Kāimén zhīhòu nĩ yǒu shé me xíngwéi?

Wǒ păo chūlái lí tāmen jiā de dàmén bù dào shí mì de yàngzi, bèi pàichūsuǒ de rén zhuā zhù le. Fāxiàn wǒ de rén méiyǒu zhuī wǒ.

Prosecutor: How did you get to know Zhao and Li? know what his job was.

Prosecutor:

Prosecutor:

Defendant:

Prosecutor:

Defendant

Prosecutor:

Defendant:

Prosecutor:

Defendant

Prosecutor:

Defendant

Prosecutor:

Defendant:

Prosecutor:

Defendant

Prosecutor:

Defendant

Defendant:

Prosecutor:

Defendant:

Defendant:
When did you come to Nanjing?

Last August. That day Zhao called me to come to stay with him for several days, but didn't tell me what to do after I came.

After you came, in your first theft, did Zhao tell you what to do?

No. He didn't tell me about the theft until we arrived at the site. I acted as the watchman outside the site.

Besides keeping watch, what else did you do?

Nothing else.

Do you know the site of the first theft?

Yes. I identified it later.

What did they steal, do you know?

MP3, PHS, computer memory bar. After the theft, the stolen things were kept by Zhao.

What about the second time?

The same afternoon, still the four of us, I also went in, Zhao broke the window, and then Li went in to open the door, then we all went in. This time we stole one necklace, two gold rings, and three silver ingots. The amount of cash is not clear. We found these things separately, and then put them together.

How did you deal with the jewelry?

We sold them together, getting $¥ 1350$. We directly gave the money to Zhao. Then we spent it on meals.

What about the third time?

Still the four of us, on the first floor of a building in a residential village. Zhao broke the window; Li went in and opened the door to let us in. This time we stole six packs of hard Zhonghua cigarettes, two bottles of Wu Liang Chun spirits, which were sold, getting $¥ 90$. However, people did not accept the Zhonghua cigarettes, because they were export cigarettes, then we smoked them ourselves. The money was also given to Zhao and we spent it together.

What about the fourth time?

The four of us went in a shop and stole $¥ 500$. The money was kept by Zhao and then spent by us together

What about the fifth time?

Three of us, without Zhao. This time Li broke the window, and then we all went in and stole a little more than $¥ 100$ in cash, about $¥ 120$. After we got back, we gave the money to Zhao.

What about the sixth time?

Still three of us, without Zhao, This time Li broke the window, and then we all went in. This time we stole a gold necklace, two rings, a jade pendant, cash and so on. 


\begin{tabular}{|c|c|c|}
\hline $\mathrm{T} 25$ & Prosecutor: & Where did the jewelry go? \\
\hline T26 & Defendant: & $\begin{array}{l}\text { They were sold, getting } ¥ 2140 \text {. Li sold } \\
\text { them. }\end{array}$ \\
\hline T27 & Prosecutor: & How did you know? \\
\hline 28 & Defendant: & $\begin{array}{l}\text { Li gave the money to Zhao after he sold } \\
\text { the jewelry, so I knew. }\end{array}$ \\
\hline 29 & Prosecutor: & What about the seventh time? \\
\hline 30 & Defendant: & $\begin{array}{l}\text { The four of us went in together. We stole } \\
\text { a mobile phone, a Zhongheng MP4, and } \\
\text { cash. }\end{array}$ \\
\hline T31 & Prosecutor: & How did you deal with these things? \\
\hline 32 & Defendant: & $\begin{array}{l}\text { The mobile phone, MP4 were confiscated } \\
\text { when we were arrested; the cash was } \\
\text { kept by Zhao. }\end{array}$ \\
\hline 33 & Prosecutor: & What about the last time? \\
\hline 34 & Defendant: & $\begin{array}{l}\text { The four of us went together. Zhao broke } \\
\text { the window, and then I went in and stole } \\
¥ 200 \text { in cash, two necklaces and two } \\
\text { rings. All of these were confiscated when } \\
\text { we were arrested. }\end{array}$ \\
\hline T35 & Prosecutor: & How were you found? \\
\hline 0 & Defendant: & $\begin{array}{l}\text { When I opened the door after the theft. } \\
\text { The person was outside the house. }\end{array}$ \\
\hline 37 & Prosecutor: & $\begin{array}{l}\text { Were the other three there when you } \\
\text { opened the door? }\end{array}$ \\
\hline סO & Defendant: & No. \\
\hline T39 & Prosecutor: & $\begin{array}{l}\text { What did you do after you opened the } \\
\text { door? }\end{array}$ \\
\hline T40 & Defendant: & $\begin{array}{l}\text { I ran out and was caught by the police } \\
\text { within ten meters from the door. The } \\
\text { person who had found me did not chase } \\
\text { me. }\end{array}$ \\
\hline
\end{tabular}

Liao (2003: 385) points out that in trials, questions and answers themselves are 'interactional entities' (or macro speech acts); the effects and results of the inner interactions of each side are their general purposes. Furthermore, the questions and answers together constitute an 'interactional entity', so the collision of the interactions---irrespective of the degree of cooperation--is to lead to an effect, which not only acts on the two sides of the interaction, but, more importantly, influences the judge, because the judge will make the decision according to this effect.

In Extract 4, the prosecutor interrogates Wu on the 8 thefts he participated in and tries to prove that he has committed the crime and therefore is guilty. In the first four turns, the prosecutor inquires into some important facts related to the 8 thefts, which serves as a preparation for the main interrogation. T5 to T40 is the interrogation on the 8 thefts, in which T5 to T12 is on the first theft, T13 to T16 on the second, T17 and T18 on the third, T19 and T20 on the fourth, T21 and T22 on the fifth, T23 to T28 on the sixth, T29 to T32 on the seventh, and T33 to T40 on the eighth. Each question asked by the prosecutor has a specific purpose, i.e., to seek an answer. Each part (questions and answers on a specific theft) also has a purpose, i.e., to find out what crime the defendant committed in that specific theft. The interrogation as a whole has its general purpose, i.e., to prove that the defendant has committed the crime and is guilty. So the extract is hierarchical in structure and purpose. Besides, the questions are organized in a logical order, i.e., from the first theft to the last, which is in accordance with "the sequence of knowing things according to conventions" (Zhang and Liu 2003: 4).

If we put all the questions asked by the prosecutor together, we can get a 'macro-question' (Liao 2003: 388 ), i.e. an accusing interrogation, which aims at proving that the defendant is guilty. See Extract 5 below:

Extract 5

Prosecutor: How did you get to know Zhao and Li?

Prosecutor: When did you come to Nanjing?

Prosecutor: After you came, in your first theft, did Zhao tell you what to do?

Prosecutor: Besides keeping watch, what else did you do?

Prosecutor: Do you know the place for the first time?

Prosecutor: What did they steal, do you know?

Prosecutor: What about the second time?

Prosecutor: How did you deal with the jewelry?

Prosecutor: What about the third time?

Prosecutor: What about the fourth time?

Prosecutor: What about the fifth time?

Prosecutor: What about the sixth time?

Prosecutor: Where did the jewelry go?

Prosecutor: How did you know?

Prosecutor: What about the seventh time?

Prosecutor: How did you deal with these things?

Prosecutor: What about the last time?

Prosecutor: How were you found?

Prosecutor: Were the other three there when you opened the door?

Prosecutor: What did you do after you opened the door?

From the above questions, we can see that in the form of questions, the prosecutor tells us a "story" (Eades 2010: 34), in which the defendant was first lured, then participated in the 8 thefts, and finally was caught by the police. The effect of this macro question is to show that the defendant did participate in the 8 thefts and played an important role, which leads to the 
conclusion: the defendant is guilty. The defendant's answers (macro-answer) also prove this point. See Extract 6 below:

\section{Extract 6}

Defendant: $\quad$ I got to know Zhao in January. I did not know what his job was.

Defendant: Last August. That day Zhao called me to come to stay with him for several days, but didn't tell me what to do after I came.

Defendant: $\quad$ No. He didn't tell me about the theft until we arrived at the site. I acted as the watchman outside the site.

Defendant: Not in the first time.

Defendant: Yes. I identified it later.

Defendant: $\quad$ MP 3, PHS, computer memory bar. After the theft, the stolen things were kept by Zhao.

Defendant: The same afternoon, still the four of us, I also went in, Zhao broke the window, and then Li went in to open the door, then we all went in. This time we stole one necklace, two gold rings, three ingots, the amount of cash is not clear. We found these things separately, and then put them together.

Defendant: We sold them together, getting $¥ 1350$. We directly gave the money to Zhao. Then we spent it on meals.

Defendant: Still the four of us, on the first floor of a building in a residential village, Zhao broke the window; Li went in and opened the door to let us in. This time we stole six packs of hard Zhonghua cigarettes, two bottles of Wu Liang Chun spirits, which were sold, getting $¥ 90$. However, people did not accept Zhonghua cigarettes, because they were export cigarettes, then we smoked them ourselves. The money was also given to Zhao and we spent it together.

Defendant: The four of us went in a shop and stole $¥ 500$. The money was kept by Zhao and then spent by us together.

Defendant: $\quad$ Three of us, without Zhao. This time Li broke the window, and then we all went in and stole a little more than $¥ 100$ in cash, about $¥ 120$. After we got back, we gave the money to Zhao.

Defendant: Still three of us, without Zhao, This time Li broke the window, and then we all went in. This time we stole a gold necklace, two rings, a jade pendant, cash and so on.

Defendant: They were sold, getting $¥ 2140$. Li sold them.

Defendant: Li gave the money to Zhao after he sold the jewelry so I knew.

Defendant: The four of us went in together. We stole a mobile phone, a Zhongheng MP4, and cash.

Defendant: The mobile phone, MP4 were confiscated when we were arrested; the cash was kept by Zhao.

Defendant: The four of us went together. Zhao broke the window, and then I went in and stole $¥ 200$ in cash, two necklaces, two rings. All of these were confiscated when we were arrested.

Defendant: When I opened the door after the theft. The person was outside the house.
Defendant: No.

Defendant: I ran out and was caught by the police within ten meters from the door. The person who had found me did not chase me.

The above answers of the defendant constitute another half of the "story" initiated by the prosecutor. In a sense, these questions fill in the blanks purposefully left by the prosecutor. Of course, in this version of "story" dominated by the prosecutor, what the defendant says is in service of the prosecutor's purpose and is thus disadvantageous for the defendant himself.

However, the defense attorney has another "story" to tell. See Extract 7 below:

\section{Extract 7}

T1 Defense attorney: Nǐ shì shuí hăn nǐ lái de?

T2 Defendant:

Zhào mǒu mǒu, tā hăn wǒ lái wán, dāngshí tā yě zhīdào wǒ méiyǒu gōngzuò.

T3 Defense attorney: Nĩ shì shénme shíhou zhīdào tāmen shì qù dàoqiè de?

T4 Defendant: Wǒ shìqián bù zhīdào, hòulái dàole difāng cái zhīdào.

T5

$\mathrm{T} 6$

Defendant:

Defense attorney:

Nǐmen dàoqiè zhīqián yǒu méiyǒu fèn gōng?

Zhò Móumóu jiăng guò, tā shuō tã fùzé bāi chuānghù, Li Mǒumǒu jìnqù, ránhòu wǒmen yīqŭ jìnqù.

Zuihòu yīcì nǐ shuō chū le mén bèi zhuā le, dāngshí shì gěi shuí fāxiàn le?

T8 Defendant

Shì gěi zhè hù rénjiā de línjū fāxiàn le, yīnwèi tā kàn zhe wǒ jìnqù, jiù zài wàimiàn děng zhe wŏ.

Defense attorney: Cóng nĩ jìnmén dào jĩngchá lái dàgài yǒu duō cháng shíjiān?

T10 Defendant: Shí jī fēnzhōng.

'T1 Defense attorney: Who asked you to come?

T2 Defendant:

Zhao, he called me to come and play, at that time he knew I didn't have a job.

Defense attorney: When did you know they went to steal?

T4 Defendant: I didn't know in advance, but only knew after I came to the site.

T5 Defense attorney: Was there division of labor before the theft?

T6 Defendant: Zhao said, he said he was responsible for breaking the window, Li went in, and then we went in together.

T7 Defense attorney: you? 
T8 Defendant: I was found by a neighbour of this family, because he watched me go in, and just waited for me outside.

T9

Defense attorney: How long was it between the time your entered the room and the time you were caught by the police?

T10 Defendant: Over 10 minutes.'

The questions asked by the defense attorney and the prosecutor about the same facts are different, see Table 1.

Now, let's examine the differences between the questions asked by the defense attorney and the prosecutor in detail. In T1, the defense attorney asks Ni shì shuí hăn nǐ lái de? Who asked you to come?', while the question asked by the prosecutor about the same fact is Nì shì shénme shíhou lái nánjīng de? 'When did you come to Nanjing?' The difference between the two questions is that the former shows that the reason for the defendant to come to Nanjing is 'he was asked by someone'; while the latter means that the defendant came to Nanjing on his own initiative, without being asked by anyone. So, the former implies that the defendant was lured or even controlled by someone to participate in the thefts while the latter has no such implications.

In T3, the defense attorney asks Nǐ shì shénme shíhou zhīdào tāmen shì qù dàoqiè de? 'When did you know they were going to steal?'; while the prosecutor's question about the same fact is Nĩ dì yīcì dàoqiè zhào mǒu mǒu yǒu méiyǒu gēn nǐ jiăng qù gànshénme? (In your first theft, did Zhao tell you what to do?)' The difference is quite obvious: 1). the nature of the defendant's behavior is different according to the questions: in the former, the defendant seems to have nothing to do with the theft because it was 'they' who 'were going to steal', so the defendant is depicted as a bystander in the first theft. However, in the prosecutor's question, the defendant is presupposed to be a participant in the theft. Notice the part nì dì yīcì dàoqiè 'your first theft'; 2). Different types of questions are asked. The former is a so-called 'wh' question, beginning with Shénme shíhou 'When', while the latter is a 'yes/no' question, which requires a 'yes' or 'no' answer. The difference is that the former gives the defendant an opportunity to make some statement which is favorable to him while the latter sets tight limits on the content of the defendant's answer (Fairclough 1992: 141), which leaves little room for the defendant to speak for himself.

In the third pair, the question asked by the defense attorney is Nimmen dàoqiè zhīqián yǒu méiyǒu fèn gōng? 'Was there division of labor before the theft?' while the prosecutor's question is Chú lio wàngfeng yi wài ni hái you shé me xíngwéi? 'Besides keeping watch, what else did you do?'. It should be pointed out that both the defense attorney and the prosecutor know that there was division of labor before the theft, and the task for the defendant was to keep watch, which was the least important role in the theft. So the purpose for the defense attorney is to show that the defendant played a minor role in his first theft. In contrast, the prosecutor's question presupposes that the defendant did something else besides keeping watch. His purpose is to induce the defendant to say more about what he did in the theft, which is of course detrimental to the defendant.

In T9, the defense attorney asks Cóng nǐ jìnmén dào jĭngchá lái dàgài yǒu duō cháng shíjiān? 'How long was it between the time your entered the room and the time you were caught by the police?' The prosecutor doesn't ask any question about this fact. So the

Table 1: Questions Asked by the Defense Attorney and the Prosecutor

\begin{tabular}{|c|c|}
\hline $\begin{array}{l}\text { 1. Nǐ shì shuí hăn nǐ lái de? } \\
\text { 'Who asked you to come?' }\end{array}$ & $\begin{array}{l}\text { 1. Nǐ shì shénme shíhou lái nánjīng de? } \\
\text { 'When did you come to Nanjing?' }\end{array}$ \\
\hline $\begin{array}{l}\text { Nĩ shì shénme shíhou zhīdào tāmen } \\
\text { shìqù dàoqiè de? } \\
\text { 'When did you know they went to steal?' }\end{array}$ & $\begin{array}{l}\text { 2. Nǐ dì yīcì dàoqiè zhào mǒu mǒu yǒu méiyǒu gēn nǐ jiăng qù } \\
\text { gànshénme? } \\
\text { 'In your first theft, did Zhao tell you what to do?' }\end{array}$ \\
\hline $\begin{array}{l}\text { 4. Cóng nǐ jìnmén dào jĩngchá lái dàgài yǒu duō cháng shíjiān? } \\
\text { 'How long was it between the time your entered the room and the } \\
\text { time you were caught by the police?' }\end{array}$ & No. \\
\hline
\end{tabular}


purpose for the defense attorney to ask this question deserves notice. By asking this question, he maybe wants to show that it was a short period between the time the defendant entered the room and the time he was caught by the police. In such a short time, the defendant couldn't steal a lot of things and thus couldn't cause serious harm to the owner of the house.

In a word, in this extract the defense attorney tries to prove that: 1) the defendant was lured by someone to participate in the thefts; 2) the defendant played a minor role in the thefts; and 3) his behavior didn't cause serious harm to the society. The overall purpose for the defense attorney is to mitigate the punishment upon the defendant. All the questions are in service for the same general purpose, so they are topically coherent. Furthermore, the extract has contextual and semantic coherence because it is a part of court interrogation and all the questions are about the defendant's thefts and thus semantically related to each other. Last but not least, the extract is coherent historically, because it refers back to what Zhao (a key figure in the thefts) said in the thefts (see T4 and T6).

\section{CONCLUSION}

Courtroom discourse is purpose-driven and coherence is essential for the realization of purpose. This paper analyzes the audio recording transcripts of two trials in China and finds that courtroom discourse is coherent semantically, topically, contextually, and historically. The findings can shed light on the linguistic mechanisms of coherence in Chinese courtroom discourse.

\section{REFERENCES}

Brown, G. and Yule, G. 1983. Discourse Analysis. Cambridge: Cambridge University Press. http://dx.doi.org/10.1017/CBO9780511805226

Danes, F. 1974. Functional sentence perspective and the organization of the text. In R Danes, ed. Papers on Functional Sentence Perspective, Prague: Academia/The Hague: Mouton; 106-128.

Eades, D. 2010. Sociolinguistics and the Legal Process. Bristol: Multilingual Matters.
Fairclough, N. 1992. Discourse and Social Change. Cambridge/Oxford: Polity Press.

Halliday, M. A. K. and Hasan, R. 1976. Cohesion in English. London: Longman.

Hu, D. H. 2010. "Cohesion of Legal Text and C-E Translation: A Case Study of Companies Law of the People's Republic of China." Journal of Mudanjiang College of Education, 123(5): 58-60.

Huang, L.F. 2008. Cohesive ties in legal text. Unpublished Ph.D. Dissertation of Southwest University of Political Science, China.

Liao, M. Z. 2003. A Study on Courtroom Questions, Responses and Their Interaction: A Linguistic Perspective. Beijing: Law Press.

Liao, M. Z. 2012. Frame analysis of courtroom discourse. Contemporary Rhetoric 4: 83-91.

Lv, 2011, A Study of Power in Chinese Courtroom Discourse. Beijing: China Social Sciences Press.

Mann, W. C. and Thompson, S. A. 1988. "Rhetorical structure theory: Toward a functional theory of text organization." Text, 8(3): 243-281. http://dx.doi.org/10.1515/text.1.1988.8.3.243

Sanders, T., Spooren, W. and Noordman, L. 1992. "Towards a taxonomy of coherence relations. " Discourse Processes. 15: 1-35. http://dx.doi.org/10.1080/01638539209544800

Sanders, T., Spooren, W. and Noordman, L. 1993. "Coherence relations in a cognitive theory of discourse representations." Cognitive Linguistics 4: 93-133. http://dx.doi.org/10.1515/cogl.1993.4.2.93

Shi, G. 2014. "Intertextuality in Chinese courtroom discourse: a critical perspective." Chinese Semiotic Studies 10 (3): 427450. http://dx.doi.org/10.1515/css-2014-0035

Tao, Y. 2009. "Theory of macro-structures and its application." Journal of Dalian Maritime University (Social Sciences Edition) 8(5): 100-102.

van Dijk, T. A. 1977. Text and Context. London: Longman.

van Dijk, T. A. 1980. Macrostructures: An Interdisciplinary Studies of Global Structures in Discourse Interaction, and Cognition. Hillsdale, NJ: Lawrence Erlbaum Associates.

Wang, L. B. 2009. "Application of macrostructure theory in discourse analysis." Journal of Heilongjiang College of Education 28 (11): 124-125.

Widdowson H G. 1978. Teaching Language as Communication. Oxford: Oxford University Press.

Xiong, T. 2002. Cohesion in the Chinese legislative text. Unpublished Master Thesis, Guangdong University of Foreign Studies, China.

Yang, X. H. and Jiang, X. L. 2014. "Coherence and incoherence of Chinese legislative text." Foreign Language Education 35(3): 36-39.

Received on 22-08-2014

Accepted on 09-09-2014

Published on 10-11-2014

DOI: http://dx.doi.org/10.6000/1929-4409.2014.03.28

(c) 2014 Guang Shi; Licensee Lifescience Global.

This is an open access article licensed under the terms of the Creative Commons Attribution Non-Commercial License (http://creativecommons.org/licenses/by-nc/3.0/) which permits unrestricted, non-commercial use, distribution and reproduction in any medium, provided the work is properly cited. 